\title{
Procedure to optimize modified atmosphere packaging for fruit
}

\author{
Patrick Varoquaux $^{a \star}$, Barbara Gouble ${ }^{a}$, Marie-Noëlle Ducamp ${ }^{b}$, Guy Self ${ }^{b}$
}

a Institut national

de la recherche agronomique, UMR 408 Sécurité

et qualité des produits d'origine végétale,

Domaine Saint-Paul,

Site Agroparc,

84914 Avignon Cedex 9,

France

b Cirad-Flhor,

Bld de la Lironde,

TA 50 / PS4,

34398 Montpellier Cedex 5, France

varoquau@avignon.inra.fr

\section{Procedure to optimize modified atmosphere packaging for fruit.}

Abstract - Introduction. The respiration of living plant tissues and the diffusion of gases through the packaging material modify the atmosphere composition in the fresh product package. This modified atmosphere (MA) can be beneficial to the storage of fruit tissues, but, if the permeances of the films are not properly optimized, the MA may be inefficient or even detrimental. To define the optimal permeances (or permeability) for $\mathrm{O}_{2}, \mathrm{CO}_{2}$ and water vapor of the packaging film, the respiration rate of plant tissue must be measured as a function of temperature and atmosphere, and the $\mathrm{O}_{2}$ and $\mathrm{CO}_{2}$ concentrations that maximize shelf life must be determined. The best combination of packaging films, type and condition of fresh produce and storage temperature may be computed and verified experimentally. Materials and methods. The work presents methods for measurement of the respiration rate of plant tissue, then the influence of temperature and the influence of $\mathrm{O}_{2}$ and $\mathrm{CO}_{2}$ contents are studied. This makes it possible to determine the optimal $\mathrm{O}_{2}$ and $\mathrm{CO}_{2}$ concentrations and the optimal gas transmission rates of packaging material. Lastly, experiments regarding the simulation of modified atmospheres are described. Conclusion. The methodology presented in our work provides helpful information to meet the need of optimal fruit and vegetable packaging.

Fruits / controlled atmosphere storage / gas exchange / polyethylene film / methods
${ }^{*}$ Correspondence and reprints

Received 29 January 2002 Accepted 6 May 2002

Fruits, 2002, vol. 57, p. 313-322 (c) 2002 Cirad/EDP Sciences All rights reserved DOI: $10.1051 /$ fruits:2002028

RESUMEN EsPañol, p. 322

\section{Méthode permettant d'optimiser l'emballage des fruits sous atmosphère modifiée.}

Résumé - Introduction. La respiration de tissus végétaux vivants et la diffusion des gaz au travers du film d'emballage modifient la composition de l'atmosphère du produit frais conditionné. Cette atmosphère modifiée (AM) peut être bénéfique au stockage des tissus de fruit, mais si la perméance du film n'est pas correctement optimisée, l'AM peut être inefficace ou même nuisible. Pour définir les meilleures perméances du film d'emballage (ou perméabilités) pour $\mathrm{O}_{2}, \mathrm{CO}_{2}$ et la vapeur d'eau, le taux respiratoire du tissu végétal doit être mesuré en fonction de la température et de l'atmosphère, et les meilleures concentrations en $\mathrm{O}_{2}$ et $\mathrm{CO}_{2}$, pour assurer la durée de conservation optimale, doivent être déterminées. La meilleure combinaison des films, du type et des conditions d'emballage du produit frais et de la température de stockage peut être modélisée et vérifiée expérimentalement. Matériel et méthodes. Le document présente les méthodes de mesure du taux respiratoire du tissu végétal, puis l'influence de la température et l'influence en $\mathrm{O}_{2}$ et $\mathrm{CO}_{2}$ sur le contenu sont étudiées. Cela permet de déterminer les concentrations optimales en $\mathrm{O}_{2}$ et $\mathrm{CO}_{2}$ et les taux optimaux de transmission de gaz au travers du film d'emballage. Enfin, des expérimentations concernant la simulation des atmosphères modifiées sont décrites. Conclusion. La méthodologie présentée dans ce travail fournit des informations utiles pour répondre au besoin d'un meilleur emballage pour les fruits et légumes.

Fruits / stockage en atmosphère contrôlée / échange gazeux / film de polyéthylène / méthode 


\section{Introduction}

Consumer demand for fresh fruit has triggered the need for packaging that maintains the freshness, the safety and the quality of these products. Research aimed at improving the quality and extending the shelf life of these commodities has been conducted in the fields of physiology, microbiology and nutrition. According to French regulations, the packaging material for prepackaged fruits and vegetables must "protect them efficiently against microbial cross-contamination" [1]. Packing induces a modification of the atmospheric composition inside the package. The respiration of living plant tissues on one hand, and the diffusion of gases through the packaging material on the other hand, modify the atmosphere composition in the package [2]

This modified atmosphere (MA) can be beneficial to the storage of plant tissues, but, if the permeances (= permeability divided by the thickness of the film) of the films are not properly optimized, the MA may be inefficient or even detrimental. For example, a film with a permeability that is too low for $\mathrm{O}_{2}$ and too high for $\mathrm{CO}_{2}$ leads to anoxia and fermentation of plant tissues [3]. The same problem may occur if the package is stored at a temperature higher than that recommended by the film supplier [4].

In order to define the optimal permeances (or permeability) for $\mathrm{O}_{2}, \mathrm{CO}_{2}$ and water vapor of the packaging film, first, we have to measure the respiration rate of plant tissue as a function of temperature and atmosphere, and then determine the $\mathrm{O}_{2}$ and $\mathrm{CO}_{2}$ concentrations that maximize shelf life. The best combination of packaging films, type and condition of fresh produce and storage temperature may be computed and verified experimentally.

\section{Measurement of the respiration rate of plant tissue}

The scarcity of data about respiration rates of plant tissues [5] has resulted in the devel- opment of new technologies, such as automatic respirometers [6].

The respiration rate of plant tissues can be measured with the jar technique [7]. Commodities are placed in jars at the required temperature. Using gas chromatography, changes in $\mathrm{O}_{2}$ and $\mathrm{CO}_{2}$ inside the containers are measured for several hours at regular time intervals. The chromatograph MTI 200 we used is equipped with two manifolds: one fitted with a MS-5A, 4-metre capillary column thermostated at $80{ }^{\circ} \mathrm{C}$ and with helium as a carrier gas at a pressure of $110 \mathrm{kPa}$; the other fitted with a capillary Poraplot Q, 6-metre column thermostated at $110{ }^{\circ} \mathrm{C}$ with argon as a carrier gas at a pressure of $193 \mathrm{kPa}$. Both manifolds were fitted with TCD (Thermal Conductimetric Detector). These analytical conditions permit the elimination of argon in the $\mathrm{O}_{2}$ peaks. The jar technique is simple and fast, but it does not allow measurements under stable atmospheric conditions.

The constant flow of atmosphere overcomes this drawback. A continuous flow of air or any gas or mixture of gases (flow rate must be constant and accurately measured) ensures a continuous renewal of the atmosphere in the containers. Comparison of gas composition at the entry and exhaust points permits calculation of the respiration rate. However, this technique is time-consuming and requires a considerable amount of gas.

The respirometer (figure 1) we developed at the Institut National de la Recherche Agronomique (INRA) allows measurements in stable conditions at any temperature and ternary gas mixture and minimizes gas consumption. The respirometer consists of two airtight $6 \mathrm{~L}$ stainless steel, cylindrical $(22 \mathrm{~cm}$ in diameter, $16 \mathrm{~cm}$ in depth) vessels in a temperature-controlled water bath (with $\pm 0.1{ }^{\circ} \mathrm{C}$ accuracy). Plant tissues are placed in one of the sealed vessels. The headspace of each vessel is flushed for $0.5 \mathrm{~h}$ with a ternary gas mixture of preset composition through three calibrated mass flow controllers (Alfagaz, Paris, France) fed from pure $\mathrm{N}_{2}, \mathrm{O}_{2}$ and $\mathrm{CO}_{2}$ cylinders. The gas composition inside the respirometer is measured with a gas chromatograph (MTI M200, Fremont, USA). Once the target atmosphere has been reached, the vents are closed. Internal 


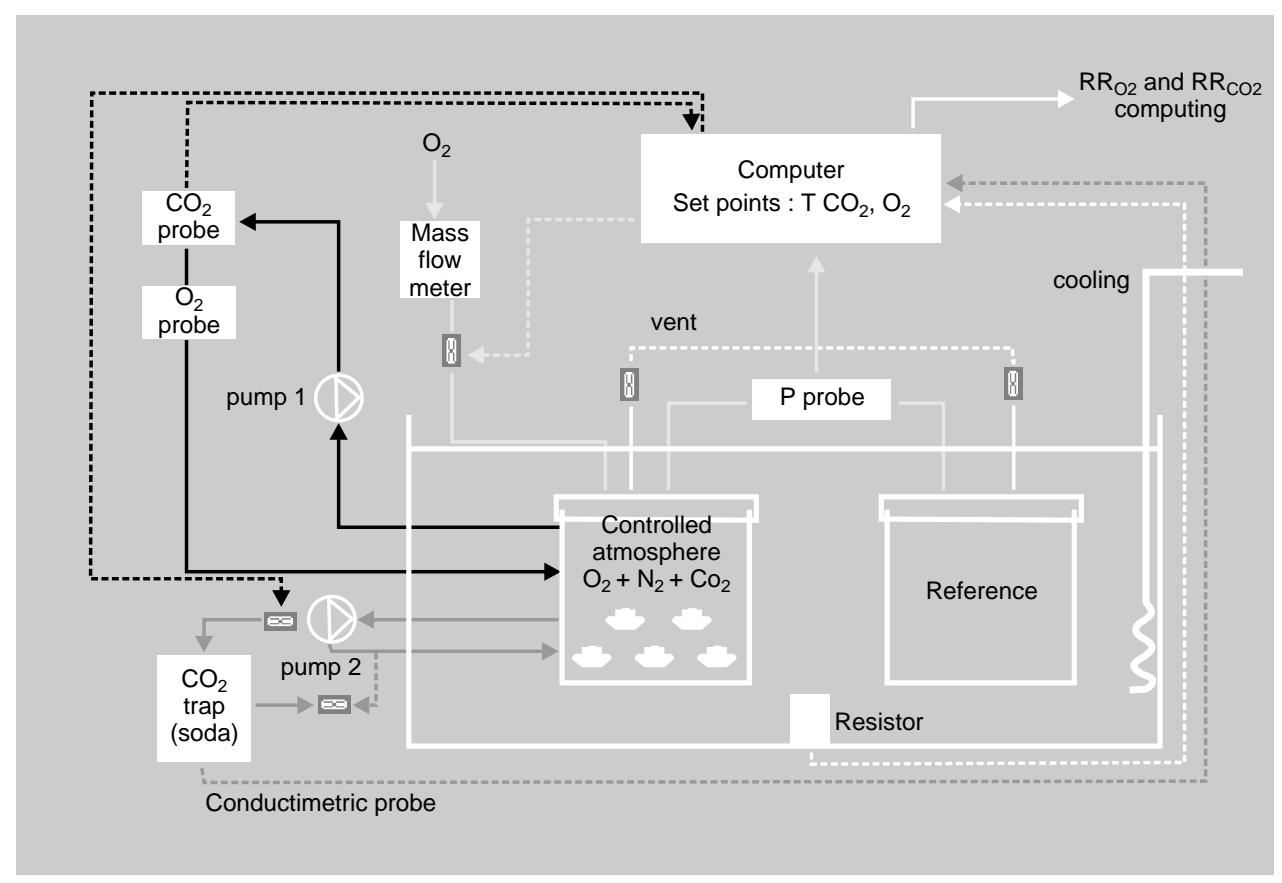

Figure 1.

Instrument used to determine the $\mathrm{O}_{2}\left(\mathrm{RR}_{\mathrm{O} 2}\right)$ and $\mathrm{CO}_{2}$ $\left(\mathrm{RR}_{\mathrm{CO} 2}\right)$ respiration rates and as well as an apparent Michaelis constant at any temperature or gas composition (gas lines: full lines, computer control lines: dotted lines). gas is pumped (pump \#1, Watson Marlow type 313 , Falmouth, England) at $300 \mathrm{~mL} \cdot \mathrm{min}^{-1}$ through an infra-red transducer (Servomex, 1510 series, Saint-Denis La Plaine, France) to measure $\mathrm{CO}_{2}$ partial pressure. If this partial pressure is $0.1 \mathrm{kPa}$ higher than the preset value of $\mathrm{CO}_{2}$ partial pressure, the computer activates an electro-valve which directs the headspace atmosphere from pump \#2 (same type as pump \#1) at a rate of $300 \mathrm{~mL} \cdot \mathrm{min}^{-1}$ through a $\mathrm{CO}_{2}$ trap filled with about $230 \mathrm{~g}$ of $0.1 \mathrm{~N}$ sodium hydroxide until the initial $\mathrm{CO}_{2}$ concentration in the sample vessel is restored. The trapping of excess $\mathrm{CO}_{2}$ results in a proportional decrease in pressure, which is detected by a highly sensitive differential pressure probe (AS Technologies, 600 series, Nîmes, France). The pressure in each vessel is then balanced by the injection of pure $\mathrm{O}_{2}$, and the initial $\mathrm{O}_{2}$ is restored through a mass flow meter (MKS, type 1179A, Le Bourget, France) into the vessel containing the plant tissue samples. The $\mathrm{CO}_{2}$ trapped in the sodium hydroxide is continuously measured by conductivity (Radiospares, LCR meter Escort ELC 1310, Beauvais, France). The computer logs the $\mathrm{O}_{2}$ injection times and the changes in conductance of the carbonated sodium hydroxide. The conductimeter is calibrated with standards of carbonated sodium hydroxide. The air flow $\left(600 \mathrm{~mL} \cdot \mathrm{min}^{-1}\right)$ generated by pumps 1 and 2, from the top to the bottom of the sample vessel, ensures the homogeneity of the respirometer atmosphere. At the end of a run, when the $\mathrm{O}_{2}$ consumption rate has been constant for at least $2 \mathrm{~h}$, the computer calculates $\mathrm{O}_{2}$ and $\mathrm{CO}_{2}$ respiration rates in mmole $\cdot \mathrm{kg}^{-1} \cdot \mathrm{h}^{-1}$. The instrument (like all other respirometers) is not able to achieve headspace levels of $0 \% \mathrm{CO}_{2}$, since the minimum $\mathrm{CO}_{2}$ partial pressure at steady state is reached when the rate of $\mathrm{CO}_{2}$ production by the plant tissue equilibrates with the $\mathrm{CO}_{2}$ trapping rate (the minimum $\mathrm{CO}_{2}$ partial pressure that can be obtained is about $0.3 \mathrm{kPa}$ in the normal configuration of the instrument).

$\mathrm{O}_{2}$ and $\mathrm{CO}_{2}$ respiration rates $\left(\mathrm{RR}_{\mathrm{O} 2}\right.$ and $\mathrm{RR}_{\mathrm{CO} 2}$ ) are calculated by the software and are expressed in mmole $\cdot \mathrm{h}^{-1} \cdot \mathrm{kg}^{-1}$.

$$
\begin{aligned}
R R_{\mathrm{O} 2}= & \left\{\left[\left(\left[\mathrm{O}_{2 \mathrm{D}}\right]-\left[\mathrm{O}_{2 \mathrm{~F}}\right]\right) / 100\right] /(273+T)\right. \\
& \times 22.4 \times \Delta t \times m\} \times(V c-V p) \times 273 \times 1000 \\
R R_{\mathrm{CO} 2} & =\left\{\left[\left(\left[\mathrm{CO}_{2 \mathrm{~F}}\right]-\left[\mathrm{CO}_{2 \mathrm{D}}\right]\right) / 100\right] /(273+T)\right. \\
& \times 22.4 \times \Delta t \times m\} \times(V c-V p) \times 273 \times 1000
\end{aligned}
$$

where:

$\left[\mathrm{O}_{2 \mathrm{D}}\right]=$ oxygen content in the container at time 0 (in $\%$ or $\mathrm{kPa}$ ),

$\left[\mathrm{O}_{2 \mathrm{~F}}\right]=$ oxygen content in the container at the time of measurement (in \% or $\mathrm{kPa}$ ), 
$\left[\mathrm{CO}_{2 \mathrm{D}}\right]=$ carbon dioxide content in the container at time 0 (in $\%$ or $\mathrm{kPa}$ ),

$\left[\mathrm{CO}_{2 \mathrm{~F}}\right]=$ carbon dioxide content in the container at the time of measurement (in $\%$ or $\mathrm{kPa}$ ),

$V c \quad=$ volume of container $($ in $\mathrm{L})$,

$V p \quad=$ volume of produce $($ in $\mathrm{L})$,

$m \quad$ = weight of plant tissue (in $\mathrm{kg}$ ),

$T=$ temperature at which the experiment is conducted (in ${ }^{\circ} \mathrm{C}$ ),

$\Delta t \quad=$ duration of the experiment (in $\mathrm{h}$ ).

The respiratory quotient (RQ) is the ratio $\left[\mathrm{RR}_{\mathrm{CO} 2} / \mathrm{RR}_{\mathrm{O} 2}\right]$. Whereas respiration rates of different plant tissues measured under air vary a lot, RQ ranges from 0.8 to 2 depending on the catabolite. For example, a fermentative respiratory pathway displays a RQ higher than 2.

\section{Influence of temperature}

The respiration rate (RR) of plant tissues increases exponentially with temperature. Gore's law (log RR is proportional to temperature), an approximation of Arrhenius' law, allows the exact calculation of $\mathrm{Q}_{10}$ ( figure 2). $\mathrm{Q}_{10}$ is the multiplication factor for the $\mathrm{RR}\left(\mathrm{RR}_{\mathrm{O} 2}\right.$ or $\left.\mathrm{RR}_{\mathrm{CO} 2}\right)$ when temperature increases by $10{ }^{\circ} \mathrm{C}$. For the respiration of plant tissues, $Q_{10}$ values range from 2 to 3 .

The example in figure 2 shows $\mathrm{RR}\left(\mathrm{RR}_{\mathrm{O} 2}\right.$ or $\mathrm{RR}_{\mathrm{CO} 2}$ ) of lychee fruit measured at four temperatures; the $\mathrm{Q}_{10}$ of oxygen consumption in our lab).

Figure 2. decimal log of respiration rates $\left(\mathrm{mmol} \cdot \mathrm{kg}^{-1} \cdot \mathrm{h}^{-1}\right)$ as function of temperature $\left({ }^{\circ} \mathrm{C}\right)$ (lychee comes from Reunion island (Cirad Flhor) and arrived $24 \mathrm{~h}$ after harvest
Lychee: changes in the and $\mathrm{CO}_{2}$ production is equal to 2.07 which is consistent with previous results for lychee ranging from 2.04 to 2.80 [8].

\section{Influence of $\mathrm{O}_{2}$ and $\mathrm{CO}_{2}$ contents}

Respiration rates also depend on the $\mathrm{O}_{2}$ and $\mathrm{CO}_{2}$ composition of the atmosphere. When a plant tissue is stored under a higher $\mathrm{CO}_{2}$ content, its RR decreases $[9,10]$ and climacteric plant tissues become less sensitive to ethylene [11]. Carbon dioxide also inhibits the growth of numerous microorganisms [12]. However, since $\mathrm{CO}_{2}$ has some phytotoxic effects, its content in storage atmospheres must not be too high. The respiration rate of plant tissues may also be lower when the $\mathrm{O}_{2}$ partial pressure is reduced, but anoxia (absence of oxygen) can also be very detrimental to the fresh produce.

Figure 3 shows some results for tomato (cv. Raïssa, red maturity stage) obtained with the respirometer at $13^{\circ} \mathrm{C}$. The increase in $\mathrm{CO}_{2}$ concentration in the sample vessel $[(5,10,15$ and 20$) \%]$ inhibits tomato $\mathrm{O}_{2}$ respiration rate $\left(\mathrm{RR}_{\mathrm{CO} 2}\right.$ not shown here) whatever the oxygen content. Without any carbon dioxide $(0 \%)$ the increase in respiration rate $\left(\mathrm{RR}_{\mathrm{O} 2}\right)$ as a function of $\mathrm{O}_{2}$ content $(3$, 10 and 21)\% is very important. This effect of $\mathrm{O}_{2}$ is still noticeable when $\mathrm{CO}_{2}$ is present in the storage atmosphere.

Respiration is considered to be as a succession of enzymatic reactions of Michaelian type and is roughly characterized by an apparent $\mathrm{Km}$, which is the substrate concentration that gives half the maximal rate of the reaction [13]. From the data for tomato, the apparent $\mathrm{Km}$ of respiration for oxygen can be calculated $(3.8 \%$ or $\mathrm{kPa})$, but this determination is not accurate because it is calculated with only three oxygen concentrations. For this reason, the respirometer was slightly modified (figure1) in order to permit the direct assessment of $\mathrm{O}_{2}$ consumption rate as a function of the residual $\mathrm{O}_{2}$ partial pressure in the headspace which allows the determination of the apparent $\mathrm{Km}$. Firstly, the $\mathrm{CO}_{2}$ was continuously 
trapped, and, secondly, the $\mathrm{O}_{2}$ injected to balance the pressure between the two vessels was replaced with pure nitrogen. A zirconium $\mathrm{O}_{2}$ probe (Arelco, type ZOA 100, Fontenay-sous-Bois, France) permitted continuous monitoring of $\mathrm{O}_{2}$ depletion in the respirometer with a sensitivity of $0.1 \mathrm{kPa}$.

Under these conditions, the respiration of the plant tissues causes a progressive decrease in $\mathrm{O}_{2}$ content in the vessel under a constant partial pressure of $\mathrm{CO}_{2}$ The instrument permits the recording of the $\mathrm{O}_{2}$ depletion as a function of time. This curve is fitted to a polynomial equation, the derivative of which is the respiration rate. It is therefore possible to measure RR as a function of $\mathrm{O}_{2}$ partial pressure and to calculate the apparent $\mathrm{Km}$

Determining the apparent $\mathrm{Km}$ for lychee at $20{ }^{\circ} \mathrm{C}$ (figure 4 ), the respiration rate is represented as a function of oxygen concentration in double inverse coordinates $\left[\left(1 / \mathrm{RR}_{\mathrm{O} 2}\right)=\mathrm{f}\left(1 / \mathrm{O}_{2}\right)\right]$. A linear regression, fitted to the experimental points, allows the calculation of the apparent $\mathrm{Km}(\mathrm{Km}=$ - a/b). For tomato at $10{ }^{\circ} \mathrm{C}$, the apparent $\mathrm{Km}$ is $5.46 \%$ (or $\mathrm{kPa}$ ) of oxygen, which means that to reduce their respiration by half, tomatoes must be stored in an atmosphere containing 5.5\% oxygen. The apparent $\mathrm{Km}$ of lychee for respiration at $20^{\circ} \mathrm{C}$ is very high (37\% of oxygen). Lowering the oxygen partial pressure will be effective in reducing the respiration rate of lychee because $\left\{\mathrm{RR}=\mathrm{RRmax} \times\left[\left(\mathrm{O}_{2}\right) /\left(\mathrm{Km}+\mathrm{O}_{2}\right)\right]\right\}$ with $\mathrm{RR}$, the respiration rate, corresponding to the concentration $\left(\mathrm{O}_{2}\right)$ and RRmax the theoretically maximum respiration rate. However, modified atmospheres will not affect the respiration rate of many plant tissues, such as mushroom and leaf vegetables, because their apparent $\mathrm{Km}$ is lower than $0.1 \mathrm{kPa}[14]$.

\section{Optimal $\mathrm{O}_{2}$ and $\mathrm{CO}_{2}$ concentration determination}

The optimal atmosphere for the storage of fruits and vegetables is estimated with the produce placed in various controlled atmos-

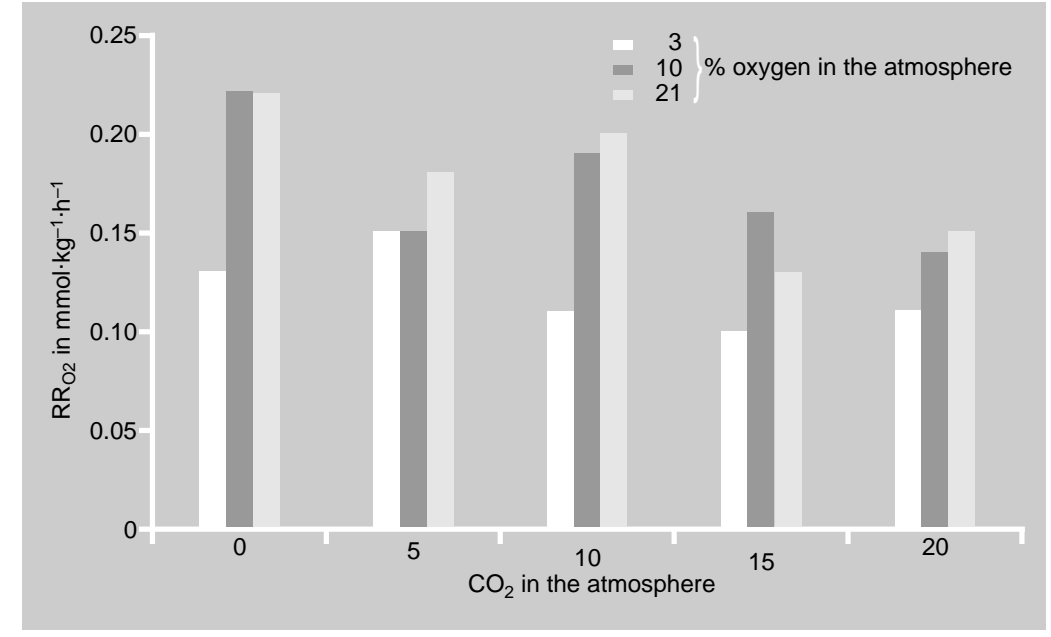

phere conditions. Samples are placed in airtight cabinets in which initial atmospheres are created with a system allowing the injection of gases. The atmospheres in the cabinets are regularly analyzed and then adjusted to preset values. As an example, we will describe the original instrument we constructed at INRA in Montfavet (France). The instrument consists of 16 airtight cabinets of around $150 \mathrm{~L}$ each. The initial atmosphere in each cabinet can be set independently as shown in figure 5 .

After the detectors have been calibrated [infra-red for $\mathrm{CO}_{2}$ and epr (electron paramagnetic resonance) probe for $\left.\mathrm{O}_{2}\right]$, the atmosphere in each cell is successively

\section{Figure 3.}

Changes in $\mathrm{O}_{2}$ respiration rate $\left(\mathrm{RR}_{\mathrm{O} 2}\right)$ of red ripe tomato cv. Raïssa at $13^{\circ} \mathrm{C}$ as a function of $\%$ of $\mathrm{O}_{2}$ and $\mathrm{CO}_{2}$ in the atmosphere.

\section{Figure 4.}

Apparent Michaelis constant, $\mathrm{Km}\left(\%\right.$ or $\mathrm{kPa}$ of $\left.\mathrm{O}_{2}\right)$ of lychee at $20{ }^{\circ} \mathrm{C}$ and $0 \% \mathrm{CO}_{2}$. Linewaever and Burk double reciprocal representation (in the figure, $K m=37 \mathrm{kPa}$ (or \%) of oxygen).

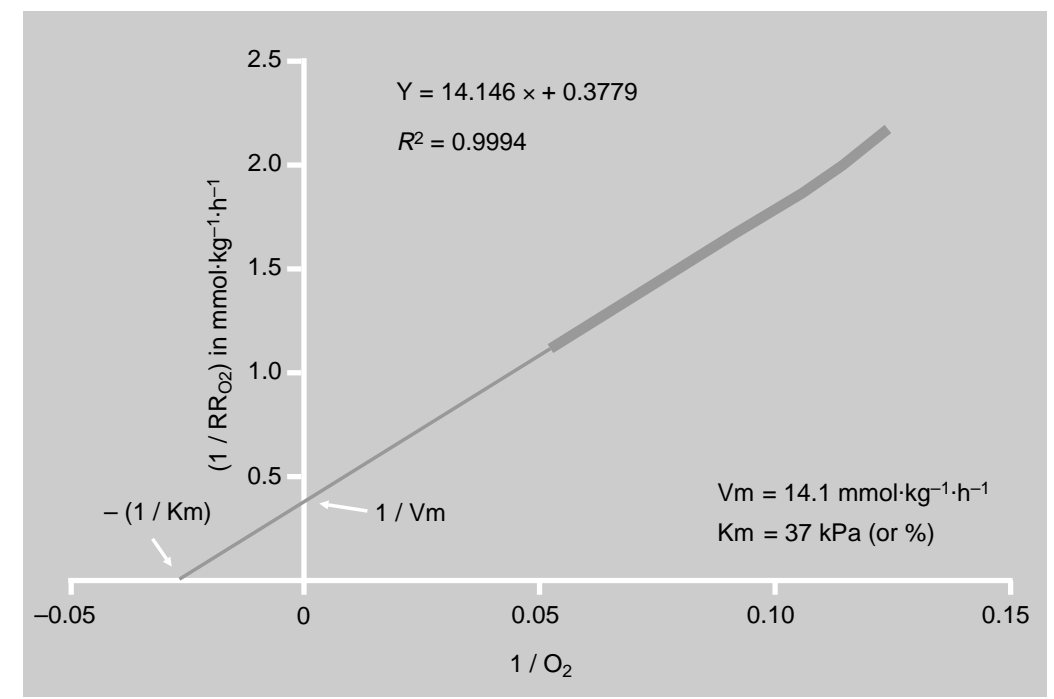


Figure 5.

Diagram of controlled atmosphere research facility at Institut National de la Recherche Agronomique (INRA), Montfavet, France.

\section{Figure 6.}

Effect of gas composition on lychee fruit discoloration assessed by sensory analysis (the lower the rank, the higher the quality) after 6 weeks at $1^{\circ} \mathrm{C}$. The significance of difference was analyzed using the rank sum method [15]. The appearance of sample $20-0\left(=20 \% \mathrm{O}_{2}-0 \% \mathrm{CO}_{2}\right)$ with low $\mathrm{RH}$ was determined significantly poorer at the $1 \%$ level, whereas sample 2-10 $\left(=2 \% \mathrm{O}_{2}-10 \% \mathrm{CO}_{2}\right)$ was estimated more attractive at the same level and sample $5-5\left(=5 \% \mathrm{O}_{2}-5 \% \mathrm{CO}_{2}\right)$ at the $0.5 \%$ level.

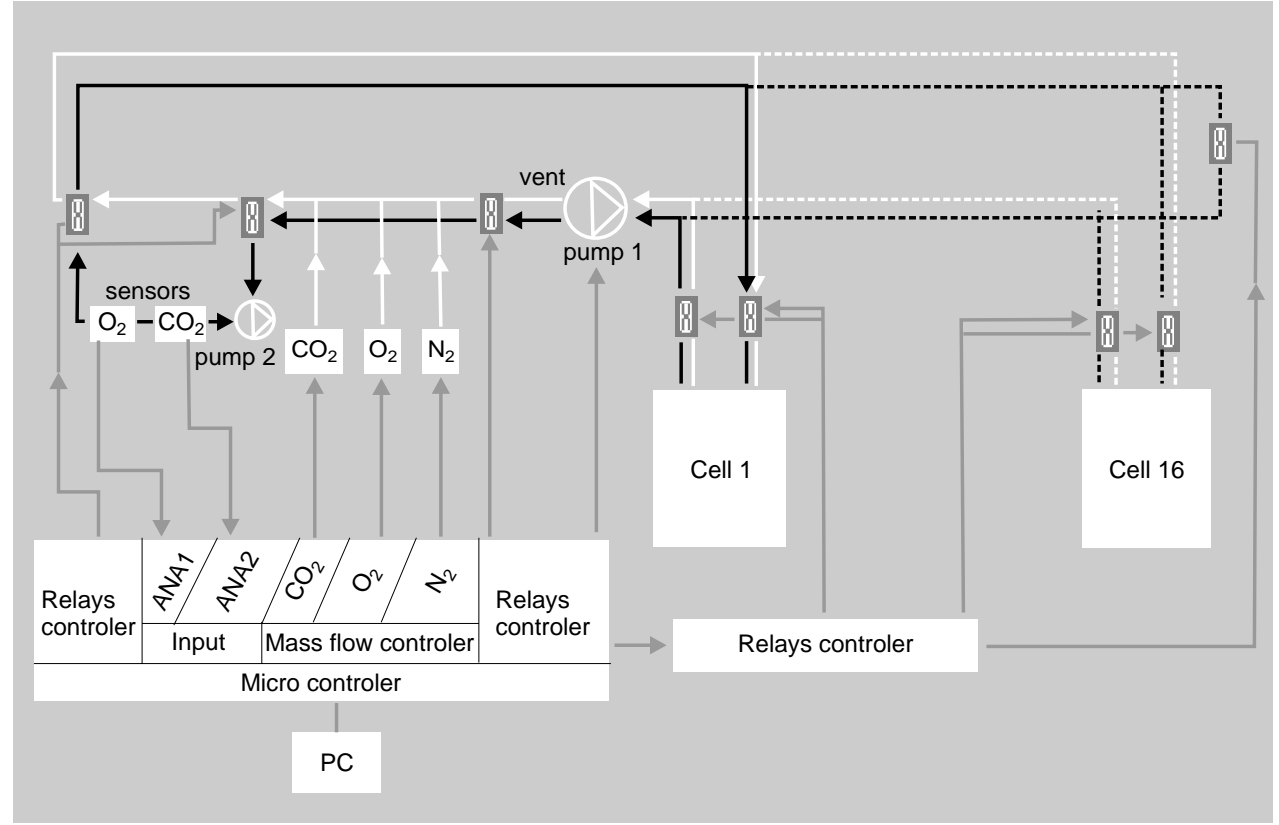

sampled. If the concentrations of the different gases are $\pm 0.1 \mathrm{kPa}$ from the preset values, the computer orders the opening of the valves of mass flow controllers to input the exact amount of $\mathrm{N}_{2}, \mathrm{O}_{2}$ and $\mathrm{CO}_{2}$ necessary to restore the preset composition. The algorithms are based on the dilution law since the system operates at about $100 \mathrm{kPa}$. Since the three mass flow controllers can be opened at the same time, the system is time and gas saving. If the gas concentrations in the cabinets deviate from the preset values (with an absolute error of $\pm 0.1 \mathrm{kPa}$ ), the procedure is repeated. This equipment allows the storage of fruits and vegetables in a controlled atmosphere, which, at intervals, can then be analyzed for their sensory, microbiological and physiological qualities. One of the most important problems for lychee is to maintain the red color of the

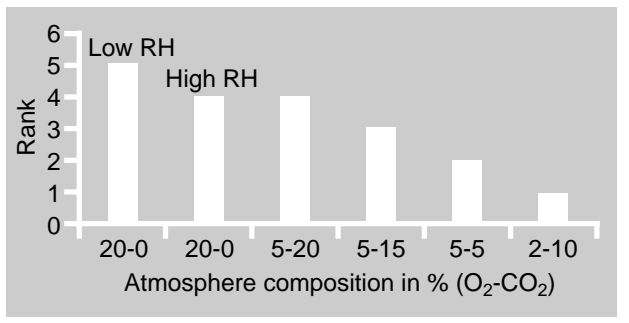

peel during storage. It is very hard to sell lychee if the peel color turns to brown. As an example, figure 6 shows the brown discoloration of lychee fruit estimated by sensory analysis (the lower the rank, the higher the quality) as a function of atmospheric composition. These results show the detrimental effect of both dehydration and high $\mathrm{CO}_{2}$ concentrations. A low oxygen partial pressure is also beneficial to the external color of lychee fruit. Conversely, low oxygen and high $\mathrm{CO}_{2}$ favor the onset of anaerobic catabolism, which results in the production of ethanol (figure 7 ).

An atmosphere containing about 2\% $\mathrm{O}_{2}$ and $10 \% \mathrm{CO}_{2}$ is very efficient in storing lychee for less than one month. For a longer period, more $\mathrm{O}_{2}$ is required to prevent the switch to anaerobic catabolism.

Knowing the respiratory parameters of plant tissues (respiration rates $\mathrm{RR}_{\mathrm{O} 2}$ and $\mathrm{RR}_{\mathrm{CO} 2}$, respiratory quotient $\mathrm{RQ}, \mathrm{Q}_{10}$ of respiration and apparent $\mathrm{Km}$ ), the conditions of packaging and the optimal gas concentration, it is possible to determine the optimal permeance of packaging film (in $\mathrm{mL} \mathrm{O}_{2}$ or $\mathrm{CO}_{2} \cdot \mathrm{m}^{-2} \cdot \mathrm{day}^{-1} \cdot \mathrm{atm}^{-1}$ ) with several mathematical models. 


\section{Optimal gas transmission rates of packaging material}

Gas diffusion through a film follows Fick's laws and, assuming a Michaelian respiration rate, oxygen concentration within a pack is governed by the following equation:

$x_{t}=x_{0}-a \int_{0}^{t} \frac{R R m \times x_{t}}{K m_{a p p}+x_{t}} \times \frac{m}{V} d t+b \int_{0}^{t} \frac{P(22 \times A}{V}(x e-x t) d t$

where

$\mathrm{x}_{\mathrm{t}} \quad=$ partial pressure of oxygen $(\mathrm{kPa})$ within the pack at any given time $t$,

$\mathrm{x}_{0}=$ initial partial pressure of oxygen $(\mathrm{kPa})$,

$\mathrm{x}_{\mathrm{e}} \quad=$ partial pressure of oxygen outside the pack (generally $21 \mathrm{kPa}$ ),

$\mathrm{RRm}=$ maximum respiration rate (mmole $\mathrm{kg}^{-1} \cdot \mathrm{h}^{-1}$,

$K m_{\mathrm{app}}=$ apparent Michaelis constant $(\mathrm{kPa})$,

$\mathrm{P}_{\mathrm{O} 2}=$ effective oxygen transmission coefficient or permeance $\left(\mathrm{mL} \cdot \mathrm{m}^{-2} \cdot 24 \mathrm{~h}^{-1} \cdot \mathrm{atm}^{-1}\right)$

$\mathrm{t} \quad=$ time $(\mathrm{h})$

$\mathrm{a}=\mathrm{a}$ coefficient 2.24,

$\mathrm{b}=\mathrm{a}$ coefficient $4 \times 10^{-5}$,

$\mathrm{V}=$ volume of the container $(\mathrm{L})$,

$\mathrm{m}=$ mass of commodity $(\mathrm{kg})$,

A = surface area of packaging over which diffusion can occur $\left(\mathrm{m}^{2}\right)$.

After a certain storage time (equilibration phase), the respiration of plant tissue will balance diffusive exchanges through the film and equation (1) can be simplified:

$a \times \frac{R R m \times x}{K m_{a p p}+x} \times \frac{m}{V}=b \frac{P_{O 2} \times A}{V}\left(x_{e}-x\right)$.

If we give to $\mathrm{O}_{2}$ the optimal value $\mathrm{O}_{\mathrm{opt}}$ attained at equilibrium, equation (2) becomes:

$P_{O 2}=\frac{a}{b} \times \frac{m \times R R_{0} \times Q_{10}{ }^{\frac{T}{10}}}{A\left(x_{e}-x_{o p t}\right)} \times \frac{x_{o p t}}{x_{o p t}+K m_{a p p}}$

where

$\mathrm{RR}_{0}=$ maximum respiration rate of the plant tissue at $0{ }^{\circ} \mathrm{C}\left(\right.$ mmole $\left.\cdot \mathrm{kg}^{-1} \cdot \mathrm{h}^{-1}\right)$,

$\mathrm{Q}_{10 \mathrm{R}}=\mathrm{Q}_{10}$ of respiration,

$\mathrm{T}=$ temperature $\left({ }^{\circ} \mathrm{C}\right)$.

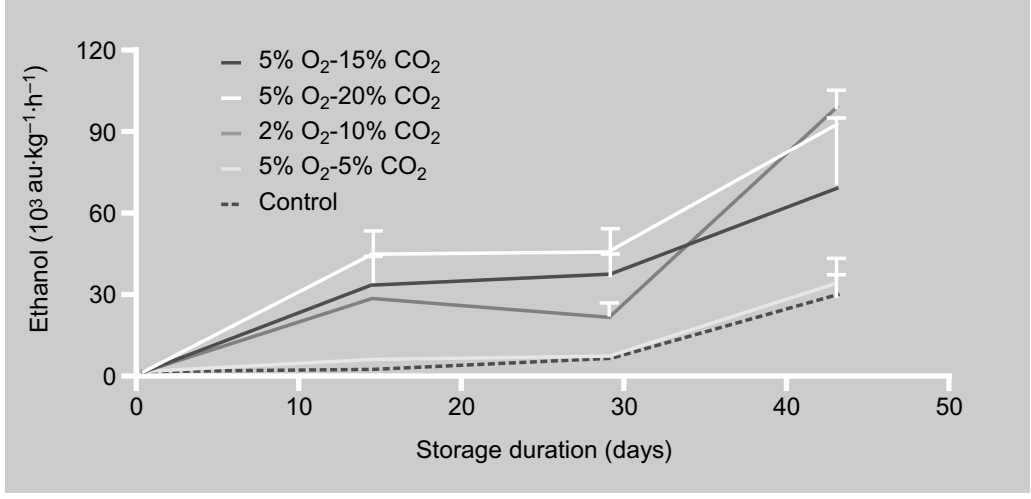

This equation shows that, at equilibrium, oxygen concentration does not depend on the headspace nor on the initial gas concentration. The injection of gas when closing the package or the punnet (actively modified atmosphere) only permits the steady state to be attained more rapidly, thereby shortening or avoiding the detrimental equilibration phase.

In equation (3), $\mathrm{X}_{\mathrm{opt}}$ is the optimal concentration in $\mathrm{O}_{2}$ previously determined by controlled atmosphere studies, $\mathrm{P}_{\mathrm{O} 2}$ is the permeance to $\mathrm{O}_{2}$ of the film which will give $\mathrm{x}_{\mathrm{opt}}$ at equilibrium and at $T$ temperature [16]. It is therefore possible to calculate the permeance of the film at $23{ }^{\circ} \mathrm{C}$ (usual temperature for measurements of permeability and permeance of packaging films).

$$
P_{O 2\left(23{ }^{\circ} \mathrm{C}\right)}=P_{O 2 T} \times Q_{10 F}{ }^{\frac{23-T}{10}}
$$

where

$\mathrm{Q}_{10 \mathrm{~F}}=\mathrm{Q}_{10}$ of permeance of the film for oxygen.

Unfortunately, the constants $\mathrm{Q}_{10 \mathrm{~F}}$ for $\mathrm{O}_{2}$ and $\mathrm{CO}_{2}$ transmission rates are difficult to obtain and generally are not given by the film suppliers. $\mathrm{Q}_{10 \mathrm{~F}}$ of micro-perforated films ranges between 1.05 and 1.15 , while that of polymeric non-perforated films is higher, between 1.4 and 1.8 [17]. If $\mathrm{Q}_{10 \mathrm{~F}}$ is known, equation (4) may be used to determine the theoretical permeance of the film at $23{ }^{\circ} \mathrm{C}$. Using very simple mathematical software it is possible to find the optimal permeability for $\mathrm{O}_{2}$ and $\mathrm{CO}_{2}$ [16].

Microperforated films with a large range of permeability to oxygen, from (1 to

\section{Figure 7.}

Effect of gas composition on ethanol production (arbitrary units, au) by lychee fruit stored at $1{ }^{\circ} \mathrm{C}$ 
200000) $\mathrm{mL} \mathrm{O}_{2} \cdot \mathrm{m}^{-2} \cdot 24 \mathrm{~h}^{-1} \cdot \mathrm{atm}^{-1}$, are now available. However this kind of film is devoid of selectivity to gases $\left[\mathrm{S}=\left(\mathrm{P}_{\mathrm{CO} 2} /\right.\right.$ $\left.\mathrm{P}_{\mathrm{O} 2}\right)=1$ for all microperforated films] and the sum of the $\mathrm{O}_{2}$ and $\mathrm{CO}_{2}$ partial pressures is always equal to $21 \%$ (or $\mathrm{kPa}$ ). Numerous commodities need storage atmospheres simultaneously poor in $\mathrm{O}_{2}$ and $\mathrm{CO}_{2}$ and, therefore, films with a selectivity much greater than 1 [18]. As an example, the selectivity of oriented polypropylene (OPP) film is 3 and that of low density polyethylene up to 7 [19]. It is possible to modify the permeance of these non-perforated polymeric films to $\mathrm{O}_{2}$ (and to $\mathrm{CO}_{2}$ at the same rate) by making films with different thicknesses, since the permeance of a film is equal to its permeability divided by its thicknesses (not valid for microperforated films). However, for commercial and mechanical reasons, the thickness of a film must be in the range (15 to 100$) \mu \mathrm{m}$.

The selectivity of new hydrophilic films such as Pebax ${ }^{\circledR}$, Sympatex ${ }^{\circledR}$ or Hytrel ${ }^{\circledR}$, ranges from 5 to 15 depending on the density of the hydrophilic groups in the copolymer, the relative humidity and the temperature. The selectivity of biofilms, such as wheat gluten and methyl cellulose, can reach 30 [20], which makes possible almost all combinations of gas composition at steady state.

It is possible, with all the acquired data, to predict changes in the atmospheric composition of an optimized modified atmosphere package.

\section{Simulation of modified atmospheres}

Equation (1) described above allows the prediction of changes in the concentration of $\mathrm{O}_{2}$ in a package. This equation is valid only if the storage temperature is stable. In the case of temperature abuse, the effect of temperature on respiration rate and on the $\mathrm{O}_{2}$ and $\mathrm{CO}_{2}$ transmission rates of films must be introduced in equation (1) with equation (4).
It should be noted that when distribution is ambient temperature, the optimal permeability of the film must be calculated for the highest temperature likely to be encountered. The modified atmosphere reached at lower temperatures, however, will not be optimal for preserving the sensory qualities of the commodity. Software developed in the Netherlands [21] and at INRA in collaboration with the University of Florida predict changes in modified atmospheres for the case of variable temperature (linear interpolation in the Dutch software or exponential in the INRA-University of Florida program). After this last step, the packaging parameters should be tested, since numerous variables are not taken into account in the theoretical calculations which are based on an extreme simplification of fruit and vegetable physiology. For example, models do not take into account microbial growth which may be responsible for a four-fold increase in the apparent respiration rate of soy bean sprouts within $14 \mathrm{~h}$ at $20{ }^{\circ} \mathrm{C}$ [22]. Some models [23] can also simulate catabolic deviation (commonly called anaerobic or fermentative catabolism), but a lot of the parameters required in the model are difficult to determine experimentally. Numerous other parameters can also interfere; for example, some plant tissues are sensitive to carbon dioxide, maturation (stage of maturity), ripening (stage of ripeness), chilling injury, etc.

\section{Conclusions}

In France, ready-to-eat fresh commodities appeared in the market two decades ago without sufficient scientific knowledge. The choice of packaging and its diffusive characteristics (OPP, $30 \mu \mathrm{m}$ to $40 \mu \mathrm{m}$ thick) were successfully determined experimentally for ready-to-eat green salads for a shelf life of up to 8 days at $8^{\circ} \mathrm{C}$. Conversely, the same choice proved to be detrimental for some grated vegetables, which need films with a higher permeability to oxygen for the same storage duration and temperature. 
The choice of a packaging film depends on many other factors not reviewed in this paper:

- industrial acceptability for its compatibility with packaging machines, sealability and printing qualities of the packaging material,

- acceptable appearance (haze, gloss and transparency) and physical performances (tear strength, dart impact, tensile strength and modulus),

$$
- \text { cost. }
$$

Moreover, the permeability of films to water vapor and to ethylene should also be taken into account, because, while very high relative humidity prevents the dehydration of leafy vegetables, it is detrimental to bulbs and mushrooms [24, 25]. Finally, the storage of climacteric fruits and many ethylene-sensitive vegetables would be improved if it were possible to eliminate or greatly reduce ethylene within the package.

Packers and fresh food processors are still looking for a more user-friendly model for choosing the optimal fruit and vegetable packaging conditions. The methodology presented here provides helpful information to meet that need.

\section{References}

[1] Anonymous, Guide de bonnes pratiques hygiéniques concernant les produits végétaux prêts à l'emploi dits de "IVe gamme ", Bull. Off. Rép. Franç. 4 (1988) 221-232.

[2] Ben-Yehoshua S., Fang D., Rodov V., Fishman S., New developments in modified atmosphere packaging, Plasticulture 106 (1995) 29-37.

[3] Kader A.A., Biochemical and physiological basis for effects of controlled and modified atmospheres on fruits and vegetables, Food Technol. 40 (1986) 99-104.

[4] Carlin F., Nguyen The C., Hilbert G., Chambroy Y., Modified atmosphere packaging of fresh "ready-to-use" grated carrots in polymeric films, J. Food Sci. 4 (1990) 1033-1038.

[5] Raghavan G.S.V., Gariepy Y., Orsat V., $M A / C A$ storage of horticultural crops, in: Blanpied G.D., Bartsh J.A., Kline S.J., Hicks J.R. (Eds.), Sixth Int. Controlled Atmos. Res. Conf., Proc., Vol. 2, Cornell Univ., Ithaca, NY, USA, 1993, pp. 719-726.
[6] Bower J.H., Jobling J.J., Patterson B.D., Ryan O.J., A method for measuring the respiration rate and respiratory quotient of detached plant tissues, Postharvest Biol. Technol. 13 (1998) 263-270.

[7] Chambroy Y., Physiologie et température des produits frais découpés, Rev. Gén. Froid 3 (1989) 78-81.

[8] Kader, http://postharvest.ucdavis.edu

[9] Peppenlenbos H.W., Van't Leven J., Evaluation of four types of inhibition for modeling the influence of carbon dioxide on oxygen consumption of fruits and vegetables, Postharvest Biol. Technol. 7 (1995) 27-40.

[10] Kader A.A., Biological bases of $\mathrm{O}_{2}$ and $\mathrm{CO}_{2}$ effects on postharvest life of horticultural perishables, in: Salveit M., Seventh Int. Controlled Atmos. Res. Conf. Proc., Vol. 4, Vegetables and Ornamental, UCD, Davis CA, USA, 1997, pp. 160-163.

[11] Bufler G., Ethylene-enhanced 1-amino-cyclopropane 1-carboxylic acid synthase activity in ripening apples, Plant Physiol. 75 (1984) 192-195.

[12] Dixon N.M., Kell D.B., The inhibition by carbon dioxide on the growth and metabolism of microorganisms, J. Appl. Bacteriol. 67 (1989) 109-136.

[13] Talasila P.C., Cameron A.C., Joles D.W., Frequency distribution of steady state oxygen partial pressures in modified atmosphere packages of cut broccoli, J. Am. Soc. Hortic. Sci. 119 (1994) 556-562.

[14] Varoquaux P., Gouble B., Barron C., Yildiz F., Respiratory parameters and sugar catabolism of mushroom (Agaricus bisporus Lange), Postharvest Biol. Technol. 16 (1999) 51-61.

[15] Kramer A., Revised tables for determining significance differences, Food Technol. 17 (1963) 124-125.

[16] Doyon G., Prudhomme J.C., François S., Rémy L., Castaigne F., Estimation rapide des perméabilités au gaz carbonique et à l'oxygène des matériaux plastiques utilisés pour les produits horticoles frais. Calculatrice $\mathrm{HP}$ et PC compatible, Ind. Alim. Agric. 4 (1996) 229-234.

[17] Exama A., Abul J., Lencki R.W., Lee L.Z., Toupin C., Suitability of plastic films for modified atmosphere packaging of fruits and vegetables, J. Food Sci. 6 (1993) 1365-1370.

[18] Fishman S., Rodov V., Peretz J., Ben Yehoshua S., Model for gas exchange dynamics in modified atmosphere package of fruits and vegetables, J. Food Sci. 66 (1995) 1083-1087. 
P. Varoquaux et al.

[19] Rogers C.E., Permeability and chemical resistance, in: Krieger R.E (Ed.), Engineering Design for Plastics, Baur E.I., New York, 1975, 682-683.

[20] Gontard N., Thibault R., Cuq B., Guilbert S., influence of relative humidity and film composition on oxygen and carbon dioxide permeabilities of edible films, Agric. Food. Chem. 44 (1996) 1064-1069.

[21] Hertog M.L.A.T.M., Peppenlenbos H.W. Evelo R.G., Tijskens L.M.M.,. A dynamic and generic model of gas exchange of respiring produce: the effects of oxygen, carbon dioxide and temperature, Postharvest Biol. Technol. 14 (1998) 335-349.

[22] Varoquaux P., Albagnac C., Nguyen The C., Varoquaux F., Modified atmosphere packag- ing of fresh beansprouts, J. Sci. Food Agric. 70 (1996) 224-230.

[23] Peppenlenbos H.W., Tijskens L.M.M., Van't Leven J., Wilkinson E.C., Modelling oxidative and fermentative carbon dioxide production of fruits and vegetables, Postharvest Biol. Technol. 9 (1996) 283-295.

[24] Benkeblia N., Varoquaux P., Gouble B., Selselet-Attou G., Respiratory parameters of onion bulbs (Allium cepa) during storage. Effect of ionising radiation and temperature, J. Sci. Food Agric. 80 (2000) 1772-1778.

[25] Roy S., Ananthewaran R.C., Beelman R.B., Modified atmosphere and modified humidity packaging of fresh mushroom, J. Food Sci. 61 (1996) 391-397.

\section{Método para optimizar el envasado de la fruta en atmósfera modificada.}

Resumen - Introducción. La respiración de tejidos vegetales vivos y la difusión de los gases a través de la película de envasado modifican la composición de la atmósfera del producto fresco acondicionado. Esta atmósfera modificada (AM) puede ser beneficiosa para el almacenamiento de los tejidos de fruta pero, si la permeancia de la película no es óptima, la AM puede ser ineficaz e incluso nociva. Para definir las mejores permeancias del película de envasado (o permeabilidades) para $\mathrm{O}_{2}, \mathrm{CO}_{2}$ y vapor de agua, debe medirse la tasa respiratoria del tejido vegetal en función de la temperatura y la atmósfera y deben determinarse las mejores concentraciones de $\mathrm{O}_{2}$ y CO 2 para garantizar una duración de conservación óptima. La mejor combinación de películas, el tipo y condiciones de envasado del producto fresco y la temperatura de almacenamiento se pueden modelizar y verificar experimentalmente. Material y métodos. El documento presenta los métodos de medida de la tasa respiratoria del tejido vegetal, posteriormente, se estudia la influencia de la temperatura y la influencia de $\mathrm{O}_{2}$ y $\mathrm{CO}_{2}$ en el contenido. Esto permite determinar las concentraciones óptimas de $\mathrm{O}_{2}$ y $\mathrm{CO}_{2}$ y los niveles óptimos de transmisión de gas a través de la película de envasado. Por último, se describen algunos experimentos relativos a la simulación de atmósferas modificadas. Conclusión. La metodología presentada en este trabajo proporciona informaciones útiles para responder a la necesidad de un mejor envasado para frutas y hortalizas.

Frutas / almacenamiento atmósfera controlada / intercambio de gases / film de polietileno / métodos

To access this journal online: www.edpsciences.org 